\title{
Incidental finding of type A aortic dissection and treated with a CT scan
}

\author{
Ali ljaz, Syed Sadeque
}

Cardiothoracic Surgery, Sheffield Teaching Hospitals NHS Foundation Trust, Sheffield, UK

Correspondence to Dr Ali ljaz; ali.jjaz@nhs.net

Accepted 8 April 2021

\section{DESCRIPTION}

A woman in her 70s with previous microemboli was under investigation for bilateral lower limb pain. A CT angiogram was ordered to identify a source and revealed dissection of the ascending thoracic aorta (figure 1). There was localised dissection extending from the aortic root up to the mid-aspect of the ascending thoracic aorta along the left anterolateral wall and focal saccular dilatation of the abdominal aorta. Normal flow was noted in all other vessels. The patient did not exhibit any other 'classical' signs or symptoms of dissection such as severe chest pain radiating through to the back. The patient was subsequently referred to cardiothoracic surgery.

After discussion in aortic multidisciplinary team, she was advised surgical intervention would be required. An ECG-gated CT scan was performed which did not reveal any evidence of aortic dissection (figure 2). The appearance of dissection was due to motion artefact.

Aortic dissection is caused by a tear of the intimal layer of the aortic wall resulting in splitting of the aorta. The disruption creates a true and false lumen as circulating blood can enter the medial layer of the aortic wall, extending the tear. This can be a life-threatening condition, that may require urgent surgery. Common risk factors include male gender, age and hypertension.

Dissection is classified anatomically by the Stanford or DeBakey system. Stanford type A involves the ascending aorta and type $\mathrm{B}$ involves only descending aorta. DeBakey type I involves both ascending and descending aorta, type II is confined to the ascending aorta and type III to the descending aorta. Type A or DeBakey I/II is an indication for urgent surgical intervention.

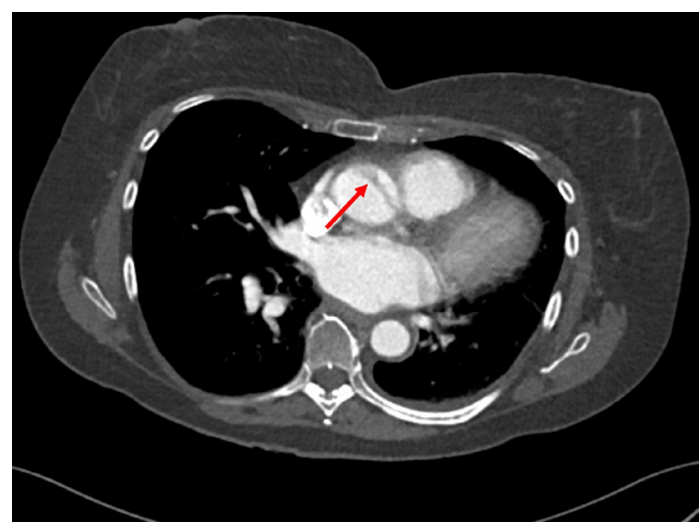

Figure 1 Non-gated CT angiogram showing apparent dissection as indicated by the arrow.

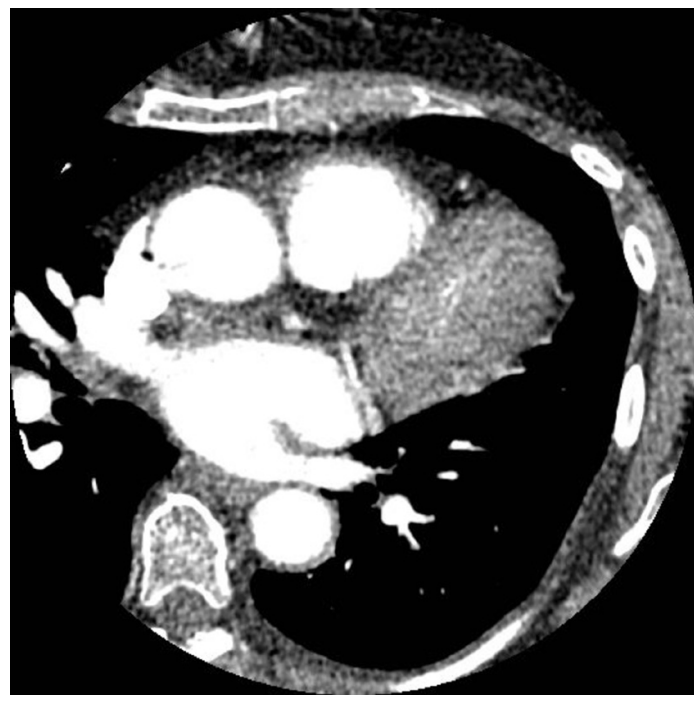

Figure 2 CT-gated scan with no evidence of dissection.

First-line imaging should be a multidetector CT scan. ${ }^{1}$ However, motion artefact is commonly seen in non-gated scans, with a prevalence varying from $57 \%$ to $93 \%$. $^{1-4}$ This is caused by cardiac and aortic wall movement that creates shadows mimicking dissection. This is most commonly seen in the aortic root and with type A dissections. ${ }^{2}$ ECG-gated CT will account for motion artefact ${ }^{5}$ and is recommended by the European Society of Cardiology and British Society of Cardiovascular Imaging. ${ }^{16}$

A false positive diagnosis in non-gated scans can have serious consequences. Haemodynamically

\section{Patient's perspective}

When we were first called in after the initial CT scan, I thought it was to do with something simple. They dropped this bombshell about this split in the aorta. I asked if it was serious and was told very serious and that I would need an urgent scan. We burst into tears; we never expected it and it knocked us off our feet. I thought at my age, I will not survive a surgery that big.

The scans were explained to us very thoroughly, but it was still scary. My children reported over the next 6 weeks that I was not myself. I spent all day thinking about it. It was a terrible time.

After having the scan and being told I did not need surgery I could have hugged the doctor. . . but we had to touch elbows instead! It was a worrying time and when I got the news it was great. I am pleased with how it all went. 


\section{Learning points}

- This case illustrates that a definitive diagnosis of acute type A aortic dissection can only be made with a gated CT scan. This avoids potential complications and unnecessary intervention.

- It is a tool to consider as part of 'triple rule out' for the patient with undifferentiated chest pain.

- Without access to ECG-gated CT scans, how would this patient have been managed differently?

compromised patients presenting with chest pain and apparent dissection on non-gated CT may be unnecessarily subjected to the significant risks of anaesthesia, open surgery and cardiopulmonary bypass. Use of a gated CT scan would remove potential misdiagnosis of dissection and prevent avoidable surgical procedures.

ECG-gated CT scans can also be used as a screening tool for 'triple rule-out' for non-specific chest pain by providing high quality imaging of the aortic, coronary and pulmonary vasculature. This allows for assessment of acute coronary syndrome, aortic dissection and pulmonary embolus in the emergency setting while minimising radiation. ${ }^{56}$

However, gated scans require specialists, are resource intensive and not widely available. This limits their current utility, particularly in acute practice. Wider implementation and access to gated CT scans may improve future diagnosis of aortic disease as well as in 'triple rule-out'.

Contributors The initial case was identified and outlined by Mr SS. Dr Al collected necessary clinical information, drafted the manuscript including obtaining images, references and patient consent. Mr SS has supervised this process and all authors have reviewed and made any necessary changes.

Funding The authors have not declared a specific grant for this research from any funding agency in the public, commercial or not-for-profit sectors.

Competing interests None declared.

Patient consent for publication Obtained.

Provenance and peer review Not commissioned; externally peer reviewed.

\section{REFERENCES}

1 Vardhanabhuti V, Nicol E, Morgan-Hughes G, et al. Recommendations for accurate CT diagnosis of suspected acute aortic syndrome (AAS)--on behalf of the British Society of Cardiovascular Imaging (BSCI)/British Society of Cardiovascular CT (BSCCT). Br J Radiol 2016:89:20150705.

2 Ko S-F, Hsieh M-J, Chen M-C, et al. Effects of heart rate on motion artifacts of the aorta on non-ECG-assisted 0.5-sec thoracic MDCT. AJR Am J Roentgenol 2005; 184:1225-30

3 Manghat NE, Morgan-Hughes GJ, Roobottom CA. Multi-detector row computed tomography: imaging in acute aortic syndrome. Clin Radiol 2005;60:1256-67.

4 Qanadli SD, El Hajjam M, Mesurolle B, et al. Motion artifacts of the aorta simulating aortic dissection on spiral CT. J Comput Assist Tomogr 1999;23:1-6.

5 McMahon MA, Squirrell CA. Multidetector CT of aortic dissection: a pictorial review. Radiographics 2010;30:445-60 www.rsna.org/rsnarights

6 Erbel R, Aboyans V, Boileau C. Esc guidelines on the diagnosis and treatment of aortic diseases. Vol. 35, European heart Journal. Paulus Kirchhof 2014:2014:2873-926.

Copyright 2021 BMJ Publishing Group. All rights reserved. For permission to reuse any of this content visit

https://www.bmj.com/company/products-services/rights-and-licensing/permissions/

BMJ Case Report Fellows may re-use this article for personal use and teaching without any further permission.

Become a Fellow of BMJ Case Reports today and you can:

- Submit as many cases as you like

- Enjoy fast sympathetic peer review and rapid publication of accepted articles

- Access all the published articles

- Re-use any of the published material for personal use and teaching without further permission

Customer Service

If you have any further queries about your subscription, please contact our customer services team on +44 (0) 2071111105 or via email at support@bmj.com.

Visit casereports.bmj.com for more articles like this and to become a Fellow 